\title{
Focus on the methods of fluvial migration architecture
}

\begin{abstract}
Fluvial migration architecture is vital both to restore the historical evolution and anatomy sedimentation structure of river reservoir architecture. Thus it's essential to figure out the proper methods of study the migration architecture. This paper aims to focus on the methods which have long been used to reveal the law of the fluvial migration. From the past to the modern, as the fast development of science and technology, approaches have been extensively promoted, which in turn enhances the technique to research the laws of the migration. This mini-review has attempted to address the development and advance of methods from the perspective of field outcrops, flume experiments, modern analogs, numerical simulation, satellite images, and seismic slices and models, which intends to promote the understanding of migration architecture of rivers. Moreover, some latest novel approaches are also highlighted in the review and demonstrate the research fronts.
\end{abstract}

Keywords: migration architecture, methods, rivers, approaches, fluvial migration
Volume 2 Issue 8 - 2017

\author{
Zhipeng Lin,' Jingfu Shan,' Le Chen, 1,2 \\ Qianjun Sun, ${ }^{2}$ Wang Yiwu ${ }^{3}$ \\ 'School of Geosciences, Yangtze University, China \\ ${ }^{2}$ School of Energy Resources, China University of Geosciences, \\ China \\ ${ }^{3}$ School of Earth and Space Sciences, Peking University, China
}

Correspondence: Jingfu Shan, Key Laboratory of Exploration Technologies for Oil and Gas Resources, Ministry of Education, School of Geosciences, Yangtze University, Wuhan 430100, Caidian,Wuhan, China, Email shangjigfu2003@163.com

Received: September 27, 2017| Published: December 22, 2017

\section{Introduction}

The migration architecture of the rivers has a significant influence on a wide range of disciplines. For example, the Geomorphology, the hydraulic, the climate, hydrologic and topographic characteristics and so on. Previous studies relating to the issue of fluvial migration include the literature of river channel patterns, ${ }^{1,2}$ deposition transport and grain size sorting, ${ }^{3-6}$ bend meandering processes, ${ }^{7-15}$ hydraulic characteristics, ${ }^{4,16}$ climate change, ${ }^{17}$ flow resistance and bank erosion. ${ }^{18,19}$ With the new technological developments during the $21^{\text {st }}$ century, an increasing number of studies intending for the deep understanding of migration theories of meandering rivers have been published. ${ }^{20}$ In the recent years, increasingly studies have tended to discover new ways towards the meandering process of rivers. Latest methods like Google Earth, ACME, and ADCP are gradually developed to complete the task. For the purpose of regulating the fishery, even the fishermen focus on the time and cause of migration of rivers. ${ }^{21}$ The methods of fluvial migration have also been the subject of intensive research in order to explain the evolution and mechanism of formation of the sinuous rivers. From the initial empirical models ${ }^{15,16,18,22,23}$ to the process-based quantitative research, ${ }^{20,24-26}$ from the field outcrops ${ }^{18,19}$ to the modern analogs, ${ }^{8,27,28}$ extensive advances have been obtained. The fluvial migration of point bars has been recently revealed by some researchers. Ghinassi \& Ielpi ${ }^{8}$ discussed the architectural and sediment logical features of Downstream-migrating fluvial point bars (DMFPB) from the perspectives of outcrops, borehole, and 3D-seismic datasets. And different modes of meander-bend transformation have also been discussed by studies. ${ }^{9,10,12,15,29}$ However, different approaches illustrated various limitations, such as the morphology models proposed are limited to steady-state conditions..$^{30}$ Some models lose sight of the influence of bank erosion, ${ }^{15}$ vegetation, the relation between channel width and depth. ${ }^{31}$ Though various migrating models are proposed, the nature of the change of channels has remained a huge challenge. Brice ${ }^{15}$ proposed the four main categories of loops (simple symmetrical, simple asymmetrical, compound symmetrical, and compound asymmetrical); Parquer ${ }^{32}$ pointed out that how the channel migration could be correlated with morphological parameters. Thus it is essential to take a look back to the methods for studying the fluvial migration process since it is difficult to understand and may get different answers by different methods (Figure 1). This review has attempted to address the development and advance of methods and intends to promote the understanding of migration architecture of rivers.

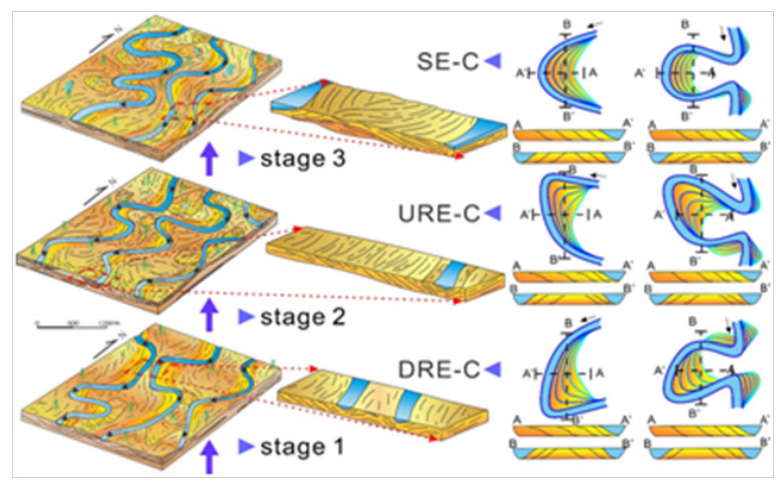

Figure I Various stage and models of different period of fluvial migration evolution process.

\section{Methods overview}

Approaches have varied from one stage to another. Basically, they can be seen as 6 stages: field outcrops, flume experiments, modern analogs, numerical simulation, satellite images, and seismic slices and models.

\section{Field outcrops}

Before 19th, data and explanation were mainly based on the observation or experiment in the field, and outcrops were the primitive and primary materials. Leopold, ${ }^{16,18}$ Wolman, ${ }^{1,22}$ and Schumm et al., ${ }^{33,34}$ had all relied on the outcrops and gained extensive achievements. Field and aerial photograph measurements of rivers have enabled direct determination of channel structures. ${ }^{35,36}$ Even by now, it is still an essential method. For example, the field study of grain size, ${ }^{6}$ Sedimentation, ${ }^{7,19,37,38}$ migrating process. ${ }^{8,9}$ The field records can preserve stratigraphic evidence which is vital to reconstructing past 
fluvial landforms and sediments. ${ }^{17}$ Therefore, in a broader perspective, the outcrop is the key to explain the past. Like the Jurassic meander plain, ${ }^{9}$ planform architecture and Stratigraphic signature are exhibited by the exhumed field outcrops, which are illustrated on the planform and vertical sections.

\section{Flume experiments}

Flume experiments are surely a great way to evaluate and quantify the morphodynamics and mechanism of the meandering migration process of channels. In the earlier ages, Many flume experiments had been completed in the Sedimentation Laboratory of the California Institute of Technology. ${ }^{1,18}$ With the development of flume techniques, numerous experiments have been taken down. They can improve the knowledge of how river hydraulics, morphology, and vegetation alter a river's planform, effect sediment mobility, and control the surrounding habitats. ${ }^{39-41}$ For various purposes, the scale of the flumes vary from $10 \mathrm{~m}$ (long) $\times 1.2 \mathrm{~m}$ (width) $\mathrm{x} 0.3 \mathrm{~m}$ (depth) ${ }^{42}$ to $15 \mathrm{~m}$ (long) $\mathrm{x}$ $0.5 \mathrm{~m}$ (width) x $0.5 \mathrm{~m}$ (depth), ${ }^{41}$ and to to $24 \mathrm{~m}$ (long) x $1.6 \mathrm{~m}$ (width). ${ }^{39}$ And thought the different flume research, different physical models of fluvial channels have been demonstrated. Moreover, the relationship between the bed slope and differential erosion and deposition can be quantified in the experiments..$^{43}$ In short, the implication of flume experiments can be well designed to illustrate the influence of various sediment supply and degree of meandering bend, thus help to reveal the laws of the migration.

\section{Modern analogs}

Since the fluvial architecture are poorly known from ancient fluvial-channel belts, one way to reconstruct it is to summarize from the modern research. Modern rivers and analogs information are increasingly becoming an important way to study the meandering rivers. The parametric echosounder (PES) is usually used in the modern rivers like the research of Río Bermejo River. ${ }^{6}$ Numerous fluvial architecture is studied with modern analogs., ${ }^{79,25,44,45}$ In the recent years, this method is also promoted with the combination of other disciplines and experiments. ${ }^{25,46}$ For the study of migration architecture, because the modern rivers can be evidently measured and tested, and data can be obtained, thus it is more convincible to do research. Like the research of Gilvear, ${ }^{14}$ Ghinassi \& Ielpi,${ }^{8}$ Zhipeng Lin, ${ }^{47}$ and Parquer. ${ }^{32}$ By investigating the river analogs and simulating the evolutionary history, the laws of the lateral and downstream migrations of rivers are aimed to be revealed.

\section{Numerical simulation}

Numerical simulation models have been widely utilized to test the morphology and planform of rivers in recent years. ${ }^{48}$ They can be developed to calculate the routing of gravel-sized sediment along a river, ${ }^{49}$ simulate the process of fluvial hydraulics and its formulation, ${ }^{50}$ or studied numerically about the evolution and migration of dunes in a river. ${ }^{51}$ Data can be originated from natural rivers, flume experiments, and underground recording. Numerical models of flow and bed topography for meandering channels have long been discussed. ${ }^{49,52}$ Models coupling the model of flow and bank erosion have then been developed. ${ }^{30}$ Willis established a 3D gridded model which improves predictions of fluvial-reservoir behavior. ${ }^{24}$

\section{Satellite images}

With the development of satellite technology, the remote sensing images have benefited a lot the study of the fluvial migration process. Combined satellite images with the modern analogs and outcrops, the sediment process and migration situation can be decently demonstrated. ${ }^{8,9,15}$ The rates and patterns of planform change over a period of time also can be obtained, ${ }^{14}$ thus the rates of channel migration and meander development can get interpreted. One of the biggest advantages is that it can demonstrate the channel morphology and planform transform, making it possible to trace the migrating process. Mithun ${ }^{25}$ has done this work and by using RS \& GIS data of Manu River, the meandering process of Manu River is examed. $\operatorname{Lin}^{10,27}$ has also used this method to quantitatively characterize the structure of meanders.

\section{Seismic slices and models}

As the seismic data is more and more precise, the techniques of seismic have provided a decent way to study the migration process of underground paleo-channels. The seismic architecture models are used to illustrate the model of rivers. ${ }^{32,53}$ High-quality 3-D seismic data is usually combined with the core and wire line log data to reveal the sedimentology and stratigraphic architecture of meandering process. ${ }^{45}$

\section{Research fronts}

A new technique, parametric echosounder (PES), is employed by Sambrook Smith et al., ${ }^{6}$ to quantify the subsurface structure of a fine-grained meandering river. This new method is illustrated to show that PES can provide high-resolution (decimeter) subsurface imaging from fine-grained rivers, solving the problem of low-resolution tasting in the fine-grained dominated rivers. Recently, a method called ADCP measurement has provided new insights towards the morphological changes of rivers. There have been attempts to try this ADCP data, namely, Acoustic Doppler Current Profiler (ADCP) data. ${ }^{20}$ By attaching an ADCP to a controlled little boat, the shortterm and small-spatial-scale changes of rivers can be recorded. Thus the geomorphological processes of meandering rivers may get tested dynamically. Moreover, the method of optimal gridding and effective property modeling ${ }^{26}$ is identified to complete the performance of rivers. Another innovation about the migration is new theories and perspectives like the $\operatorname{Lin}^{10,12}$ and Parquer. ${ }^{32}$ In their research, the method is applied to satellite images of a fluvial system and then extracts the laws of migration, ultimately, reconstructing the paleolocations of the river.

\section{Conclusion}

The short review article has reported the latest development and evaluation of the approaches which are used to study the meandering migration of rivers. With the intensive ranges of methodological framework of migration research, it can be concluded that this review has provided a tendency for the further development of fluvial migration. Furthermore, the tendency is pointed out, which counts a great deal to the scientific work. From the development of field outcrops, flume experiments, modern analogs, numerical simulation, satellite images, and seismic slices and models, it is essential to note that the leading edge is just on the way. By applying the newest data and technique of seismic, internet, instruments, and mind, ideas will surely be promoted and thus help to empower the development of the research for the fluvial system.

\section{Acknowledgements}

The project received co-financial support from the National Natural Sciences Fund "Research on Spatiotemporal Variations Mechanism of Lateral Accretion within Point Bar Based on Conditions of Physical Simulation" (41372125), and thanks are also given to the guidance of Prof. Jingfu Shan, Yangtze University. 


\section{Conflicts of interest}

None.

\section{Funding}

None.

\section{References}

1. Leopold LB, Wolman MG. River channel patterns: braided, meandering, and straight: US Government Printing Office, China;1957.

2. Wolman MG, Miller JP. Magnitude and frequency of forces in geomorphic processes. The Journal of Geology. 1960;68:54-74.

3. Cook KL, Turowski JM, Hovius N. A demonstration of the importance of bedload transport for fluvial bedrock erosion and knickpoint propagation. Earth Surf Proc Land. 2013;38(7):683-695.

4. Allen J. A quantitative model of grain size and sedimentary structures in lateral deposits. Geological Journal. 1970 7(1):129-146.

5. Parker G, Andrews E. Sorting of bed load sediment by flow in meander bends. Water Resour Res. 1985;21(9):1361-1373.

6. Sambrook Smith GH, Best JL, et al. The alluvial architecture of a suspended sediment dominated meandering river: the Rio Bermejo, Argentina. Sedimentology. 2016;63(5):1187-1208.

7. Bluck B. Sedimentation in the meandering River Endrick. Scottish Journal of Geology. 1971;7:93-138.

8. Ghinassi M, Ielpi A, Aldinucci M, et al. Downstream-migrating fluvia point bars in the rock record. Sedimentary Geology. 2016;334:66-96.

9. Ielpi A, Ghinassi M. Planform architecture, stratigraphic signature and morphodynamics of an exhumed Jurassic meander plain (Scalby Formation, Yorkshire, UK). Sedimentology. 2014;61(7):1923-1960.

10. Lin Z, Shan J, Chen L. Geomorphology Processes of Channel Planform Migration on Meandering Rivers. Acta Geographica Sinica. 2017;91:134-135.

11. Lin Z, Chen L, Shan J, et al. Migration structures of meandering channels. International Journal of Information Research and Review. 2017;4(6):4213-4221.

12. Lin Z, Chen L, Shan J, et al. Channel Planform Migration Architecture of Meandering Rivers. Asian Journal of Science and Technology. 2017;8(6):4902-4911.

13. Chen L, Lin Z, Yin T, et al. Meandering Process and Migration Architecture:Based on the Nowitna River. Earth Science Research. 2017;6(2):76-90.

14. Gilvear D, Winterbottom S, Sichingabula H. Character of channel planform change and meander development:Luangwa River, Zambia. Earth Surf Proc Land. 2000;25(4):421-436.

15. Brice JC. Evolution of meander loops. Geological Society of America Bulletin. 1974. 85(4):581-586.

16. Leopold LB, Maddock T. The hydraulic geometry of stream channels and some physiographic implications:US Government Printing Office, USA;1953.

17. Macklin M, Lewin J, Woodward J. The fluvial record of climate change. Phil Trans R Soc A. 2012;370:2143-2172.

18. Leopold LB. Flow resistance in sinuous or irregular channels:US Government Printing Office, USA;1960.

19. Hooke J. Magnitude and distribution of rates of river bank erosion. Earth Surf Proc Land. 1980;5(2):143-157.
20. Kasvi E, Laamanen L, Lotsari E, et al. Flow Patterns and Morphological Changes in a Sandy Meander Bend during a Flood-Spatially and Temporally Intensive ADCP Measurement Approach. Water-Sui. 2017;9(2):106.

21. Islam BN, Talbot G. Fluvial migration, spawning, and fecundity of Indus river hilsa, Hilsa ilisha. Transactions of the American Fisheries Society. 1968;97(4):350-355.

22. Leopold LB, Wolman MG. River meanders. Geological Society of America Bulletin. 1960;71:769-793.

23. Hooke J. Processes of channel planform change on meandering channels in the UK. Changing river channels. 1995;87-115.

24. Willis BJ, Tang H. Three-dimensional connectivity of point-bar deposits. J Sediment Res. 2010;80:440-454.

25. Mithun D, Dabojani D, Misbah U. Evaluation of meandering characteristics using RS \& GIS of Manu River. Journal of Water Resource and Protection. 2012;4(3):163-171.

26. Meirovitz CD, Stright L, Hubbard SM, et al. The influence of intra-and inter-channel architecture in selecting optimal gridding for field-scale reservoir simulation. AAPG Search and Discovery, Canada; 2016.

27. Lin Z. Channel Planform Migration Architecture of Meandering Rivers. Journal of Geology \& Geophysics. 2017. p. 3.

28. Munck SD, Gauthier Y, Bernier M, et al. River predisposition to ice jams:a simplified geospatial model, Canada; 2016.

29. Lin Z, Chen L, Shan JF. A Review:Indicative Function of Sequence Stratigraphy on Fluvial Type. International Journal of Development Research. 2017;7:13736-13741.

30. Darby SE, Alabyan AM, Van de Wiel MJ. Numerical simulation of bank erosion and channel migration in meandering rivers. Water Resour Res. 2002;38(9):2-21.

31. Fernandez R. Effect of width-to-depth ratio on the mean flow velocities for a Kinoshita meander bend, USA;2012.

32. Parquer MN, Collon P, Caumon G. Reconstruction of Channelized Systems Through a Conditioned Reverse Migration Method. Mathematical Geosciences. 2017;49(8):965-994.

33. Schumm SA, Lichty RW. Channel widening and flood-plain construction along Cimarron River in southwestern Kansas: US Government Printing Office, USA; $1963.88 \mathrm{p}$

34. Schumm SA. Sinuosity of alluvial rivers on the Great Plains. Geological Society of America Bulletin. 1963;74(9):1089-1100.

35. Nami M. An exhumed Jurassic meander belt from Yorkshire, England. Geological Magazine. 1976;113(1):47-52.

36. Olivarius M, Weibel R, Friis $H$, et al. Provenance of the Lower Triassic Bunter Sandstone formation: implications for distribution and architecture of aeolian vs. fluvial reservoirs in the North German Basin. Basin Research. 2015;29(S1):113-130.

37. Miall AD. Fluvial depositional systems: Springer; 2014.

38. Jackson RG. Depositional model of point bars in the lower Wabash River. J Sediment Res. 1976;46(3):579-594.

39. Javernick L, Bertoldi W. Quantification of river hydraulics, morphology, and vegetation interactions in flume experiments: A deeper look at vegetation encroachment management. EGU General Assembly Conference Abstracts. 2017;19:7383.

40. Wang WJ, Huai WX, Thompson S, et al. Drag coefficient estimation using flume experiments in shallow non-uniform water flow within emergent vegetation during rainfall. Ecological Indicators. 2017. 
41. Pagliara S, Kurdistani SM. Flume experiments on scour downstream of wood stream restoration structures. Geomorphology. 2017;279:141149.

42. Kuang H. Physical and Numerical Modelling Study of Meandering in Fluvial Rivers Cardiff School of Engineering: Cardiff University, $\mathrm{UK} ; 2011$.

43. Sklar LS, Fadde J, Venditti JG. Translation and dispersion of sediment pulses in flume experiments simulating gravel augmentation below dams. Water Resour Res. 2009;45(8).

44. Stouthamer E, Cohen KM, Gouw MJP. Avulsion and its implications for fluvial-deltaic architecture: insights from the Holocene Rhine-Meuse delta. SEPM Special Publication. 2011;97:215-232.

45. Labrecque PA, Hubbard SM, Jensen JL, et al. Sedimentology and stratigraphic architecture of a point bar deposit, Lower Cretaceous McMurray Formation, Alberta, Canada. Bulletin of Canadian Petroleum Geology. 2011;59(2):147-171.

46. Blum M, Martin J, Milliken K, et al. Paleovalley systems: Insights from Quaternary analogs and experiments. Earth-Sci Rev. 2013;116:128169.
47. Lin Z, Shan J, Chen L. Meticulous Depiction and Genetic Mechanism of Unconformity Belt Structure. Earth Science Research. 2017;6(2):19.

48. Asahi K, Shimizu Y, Nelson J, et al. Numerical simulation of river meandering with self-evolving banks. Journal of Geophysical Research:Earth Surface. 2013;118(4):2208-2229.

49. Hoey TB, Ferguson R. Numerical simulation of downstream fining by selective transport in gravel bed rivers: Model development and illustration. Water Resour Res. 1994;30(7):2251-2260.

50. Morvan H, Knight D, Wright N, et al. The concept of roughness in fluvial hydraulics and its formulation in 1D, 2D and 3D numerical simulation models. Journal of Hydraulic Research. 2008;46(2):191-208.

51. Khosronejad A, Kozarek JL, Palmsten ML, et al. Numerical simulation of large dunes in meandering streams and rivers with in-stream rock structures. Advances in Water Resources. 2015;81:45-61.

52. Rana SA, Simons DB, Mahmood K. Analysis of Sediment Sorting in Alluvial Channel. Journal of the Hydraulics Division . 1973;99(11):19671980.

53. Everts A, Thang H, Energy L. Best Practices in Seismic Constraining of 3D Reservoir-Architecture Models. Third EAGE Integrated Reservoir Modelling Conference, Malaysia; 2016. 